\title{
Acute Toxicity and Antipyretic Activities of a Methanolic Extract of Alchornea cordifolia Leaves
}

\author{
K. E. Effo ${ }^{{ }^{*}}$, G. Kouakou-Siransy ${ }^{1}$, G. Irie-Nguessan ${ }^{1}$, R. W. Sawadogo ${ }^{2}$, I. L. Dally ${ }^{3}$, A. B. Kamenan ${ }^{1}$, \\ L. S. Kouakou ${ }^{1}$, J. Kablan-Brou ${ }^{1}$
}

\begin{abstract}
${ }^{1}$ Laboratoire de Pharmacologie et de Physiologie, UFR des Sciences Pharmaceutiques et Biologiques, Université Félix Houphouët Boigny, Abidjan, Côte d’Ivoire; ${ }^{2}$ Laboratoire de Pharmacologie et de Toxicologie, Institut de Recherche en Sciences de la Santé (IRSS/CNRST), Ouagadougou, Burkina Faso; ${ }^{3}$ Laboratoire de Galénique, UFR des Sciences Pharmaceutiques et Biologiques, Université Félix Houphouët Boigny, Abidjan, Côte d’Ivoire.
\end{abstract}

Email: *effoet@yahoo.fr

Received August $9^{\text {th }}, 2013$; revised September $12^{\text {th }}, 2013$; accepted September $28^{\text {th }}, 2013$

Copyright (c) 2013 K. E. Effo et al. This is an open access article distributed under the Creative Commons Attribution License, which permits unrestricted use, distribution, and reproduction in any medium, provided the original work is properly cited.

\begin{abstract}
Alchornea cordifolia (Euphorbiaceae) is a very prized plant among traditional healers in Africa. Its leaves are used for its antipyretic properties in traditional areas. The aim of our study is to determine the acute toxicity and the antipyretic activity of a methanolic extract of Alchornea cordifolia leaves. Acute toxicity was assessed by measuring mortality, changes in body weight, spontaneous movements, and normal rectal temperature in mice. Antipyretic activity was evaluated by brewer's yeast-induced hyperpyrexia in rats according to Teotino method (1963). The antipyretic effect of methanolicextract of Alchornea cordifolia leaves was compared with paracetamol (100 mg/kg bw) orally. Groups of mice treated with doses of $6500 ; 3250 ; 1625$ and $812.5 \mathrm{mg} / \mathrm{kg}$ of the extract did not show any mortality, nor significant alteration of body weight, nor alteration of spontaneous movements. However, incomplete reversed dose-dependent hypothermic activity was observed with doses of 50.78; 101.56; 203.12; 406.25; and $812.5 \mathrm{mg} / \mathrm{kg}$ p.o. of the extract, showing acute toxicity of this plant. In the antipyretic assay, the extract with doses of 50.78; 101.56; 203.12; 406.25; and $812.5 \mathrm{mg} / \mathrm{kg}$ p.o. exhibited a significant dose-dependent antipyretic activity similar to paracetamol (100 mg/kg bw) in rats. Thus Alchornea cordifolia may inhibit prostaglandins-biosynthesis from hypothalamus. Our results support claims on its traditional uses in management of fever. However Alchornea cordifolia may affect hypothalamus not only during fever but also when body temperature is normal.
\end{abstract}

Keywords: Alchornea cordifolia; Acute Toxicity; Brewer’s Yeast; Hypothermia

\section{Introduction}

Alchornea cordifolia (Euphorbiaceae) is a plant that is widely used in traditional medicine in Africa, from Senegal to Cameroon, as a remedy for several diseases. Its leaves are renowned for being febrifuge [1]. Previous studies revealed no mortality in mice in acute toxicity tests, several pharmacological activities such as antimicrobial [2-4], antiameobic [5], antimalarial [6], anti-inflammatory [7,8], antispasmodic [9], antioxidant [10], antidiarrheic [11], and anti-stress properties [12]. However, there is no existing pharmacological data that indicated the antipyretic activity of Alchornea cordifolia. Thus, the aim of our study was to determine the acute toxicity and the antipyretic activity of the methanolic extract of Alchornea cordifolia leaves in rats.

\footnotetext{
"Corresponding author.
}

\section{Materials and Methods}

\subsection{Plant Material}

Fresh Alchornea cordifolia (Schum. and Thonn.) leaves were harvested in the Floristic National Center of Abidjan and the collected leaves were given to the botanic expert Prof Aké-Assi Laurent affiliated with the University of Cocody (Abidjan), who verified their uniformity with the specimens previously deposited and catalogued in the herbarium of the Floristic National Center of Abidjan. The leaves were collected and dried in darkness in a $25^{\circ} \mathrm{C}$ air-conditioned room

\subsection{Experimental Animals}

Mice (Mus musculus) (15 - $34 \mathrm{~g}$ ) and rats (Rattus norvegicus) (weighing 150 - 286 g) were purchased from 
Department of Nutrition and Pharmacology of the University of Cocody (Abidjan, Côte d'Ivoire). The animals were then bred at the Department of Pharmacology of the faculty of pharmacy of the University of Cocody. All animals were kept in the room maintained under environmentally controlled conditions of $24^{\circ} \mathrm{C} \pm 1^{\circ} \mathrm{C}$ and 12 $\mathrm{h}$ light - $12 \mathrm{~h}$ dark cycle. The animals had free access to water and food and were acclimatized at least 1 week before starting the experiments. The animals were cared for and treated according to the principles of care for, and use of, laboratory animals, formally approved by the Board of Ethics of the Cocody University, in compliance with the Guide for Care and Use of Laboratory. And before the experiments they were fasted overnight with water ad libitum.

\subsection{Chemicals}

Methanol (Sigma), sodium carboxy-methyl-cellulose (CMC) Sigma (France). Paracetamol: (Doliprane 100 mgpoudrepour solution buvable) (Sanofi Aventis), brewer's yeast Arkogélules (Arkopharma) were used in this study.

\subsection{Methanolic Extract}

The fine powder ( $200 \mathrm{~g}$ ) of dried leaves were macerated for $24 \mathrm{~h}$ at room temperature in $700 \mathrm{ml}$ of methanol. The methanolic extract obtained were dried in a rotavapor (Büchi R180) and conserved at $4^{\circ} \mathrm{C}$, and aliquots of dried powder were used for pharmacological studies after suspending in $2 \%$ CMC.

For acute toxicity test, the stock solution was concentrated at $650 \mathrm{mg} / \mathrm{ml}$. Three other ranges of concentration were prepared from this stock solution by successive dilutions in $1 / 2(325 \mathrm{mg} / \mathrm{ml}, 162.5 \mathrm{mg} / \mathrm{ml}$, and 81.25 $\mathrm{mg} / \mathrm{ml}$ ).

We used successively for the hypothermic activity and antipyretic activity, solutions concentrated at $81.25 \mathrm{mg} / \mathrm{ml}$, $40.62 \mathrm{mg} / \mathrm{ml}, 20.31 \mathrm{mg} / \mathrm{ml}, 10.15 \mathrm{mg} / \mathrm{ml}$ and $5.07 \mathrm{mg} / \mathrm{ml}$

\subsection{Acute Toxicity Test}

Mortality, body weight changes and spontaneous motor activity were assessed in mice and hypothermic activity in rats.

\subsection{Spontaneous Motor Activity (SMA)}

A multi-counter activity cage, Letica activity cages (LE 886) connected to AM1051 (Benwick electronics) data logger were used for this study. The AM1051 data logger is provided with two layers of infrared sensor placed horizontally to monitor the rearing, mobile and static activities, as well as the active and mobile times. Mice were singly placed in each cage and activity was automatically recorded by the instrument for $5 \mathrm{~min}$. Each mouse was used only once. The extracts (50.78; 101.56; 203.12; 406.25; and $812.5 \mathrm{mg} / \mathrm{kg}$ p.o.) were administrated to five groups of mice $(n=6)$ and control group received CMC. SMA measurements started one hour after the administration of the extract and the fourth hour and subsequently every two days for 14 days after treatment.

\subsection{Effect on Normal Body Temperature (Hypothermic Activity)}

Rats weighing 150 - 286 g were divided into six groups of six animals. Initial rectal temperatures were recorded using a 12 channel electric thermometer (LETICA Scientific instruments), model 812 RS, PANLAB s. L, Barcelona. Then extract (50.78 mg/kg; $101.56 \mathrm{mg} / \mathrm{kg} ; 203.12$ $\mathrm{mg} / \mathrm{kg} ; 406.25 \mathrm{mg} / \mathrm{kg} ; 812.5 \mathrm{mg} / \mathrm{kg}$ ) was given orally. Temperature changes in body temperature values before and after drug administration were recorded.

\subsection{Brewer's Yeast-Induced Hyperthermia in Rats}

Rats weighing 180 - 220 g were divided into six groups of six animals. Initial rectal temperatures were recorded using a 12 channel electric thermometer (LETICA scientific instrument), model 812 RS, PANLAB s. L, Barcelona. Hyperthermia was induced in rats according to the method of Teotino et al. [8] by subcutaneous injection of $1 \mathrm{ml} / 100 \mathrm{~g}$ body weight of $20 \%$ brewer's yeast. When the temperature was at a peak, $18 \mathrm{~h}$ after yeast injection, only rats which developed satisfactory pyrexia $\left(0.6^{\circ} \mathrm{C}\right.$ or more increase in rectal temperature) were used. Then extract (50.78 mg/kg; 101.56 mg/kg; 203.12 mg/kg; 406.25 mg/kg; $812.5 \mathrm{mg} / \mathrm{kg}$ ) was given orally $24 \mathrm{~h}$ after yeast injection. Paracetamol $(100 \mathrm{mg} / \mathrm{kg}$, p.o.) served as the reference drug for comparing the antipyretic action of extract and the rectal temperatures of animals were recorded at $1 \mathrm{~h}$ interval for $4 \mathrm{~h}$ following drug treatment.

The results are expressed as percentage $[13,14]$ :

Percent reduction

$=\frac{(\text { yeast-induced pyrexia }- \text { post-treatment temperature }) \times 100}{\text { Yeast-induced pyrexia }}$

\subsection{Statistical Analysis}

The results are expressed as mean value \pm S.E.M. Friedman's test was applied to the results. Mean values were considered significantly different when $\mathrm{P}<0.05$.

\section{Results}

\subsection{Acute Toxicity}

\section{Mortality and body changes weight}

No death was observed nor a significant changes in 
weight (Table 1).

\section{Spontaneous motor activity}

After a two-week observation, the methanolic extract from Alchornea cordifolia engendered no significant modification of spontaneous motor activity.

\section{Effect on normal body temperature}

The doses of $203.125 \mathrm{mg} / \mathrm{kg}, 406.25 \mathrm{mg} / \mathrm{kg}$ and 812.5 $\mathrm{mg} / \mathrm{kg}$, presented hypothermic activity $(\mathrm{p}<5 \%)$. The methanolic extract of Alchornea cordifolia causes a hypothermia that is not totally reversed at the end of a four-hour time (Figure 1).

\subsection{Antipyretic Activity}

Figure 2 show the antipyretic activity. During four (04) hours, the methanolic extract of Alchornea cordifolia administered at $812.5 \mathrm{mg} / \mathrm{kg}$ to the rat presented an antipyretic effect superposable to that of the paracetamol administered at $100 \mathrm{mg} / \mathrm{kg}$. The doses of $203.125 \mathrm{mg} / \mathrm{kg}$, $406.25 \mathrm{mg} / \mathrm{kg}$ presented also a statistically significant antipyretic activity $(\mathrm{p}<5 \%$ ). The antipyretic effect is totally reversed after 4 hours.

Figure 3 shows the percentage of hyperthermia inhibition after two hours. We noted a reduction of the hyperthermia upper to $80 \%$ with $203.125 \mathrm{mg} / \mathrm{kg}, 406.25 \mathrm{mg} / \mathrm{kg}$ and $812.5 \mathrm{mg} / \mathrm{kg}$. In doses lower than $203.125 \mathrm{mg} / \mathrm{kg}$, we noted a percentage of reduction lower than $50 \%$.

\section{Discussion}

Alchornea cordifolia is a plant which is very currently used in traditional medicine for the treatment of several

Table 1. Mortality and body changes weight.

\begin{tabular}{|c|c|c|c|c|}
\hline Substance & mice number at the beginning & mice number at the end & Average initial weight (g) & Average weight at the end (g) \\
\hline CMC $2 \%$ & 8 & 8 & 22.4 & 24.5 \\
\hline MEAC: 81.25 mg/kg & 8 & 8 & 22.2 & 22.4 \\
\hline MEAC: 162.5 mg/kg & 8 & 8 & 22.2 & 23.7 \\
\hline MEAC: 325 mg/kg & 8 & 8 & 22.3 & 22.3 \\
\hline MEAC: $6500 \mathrm{mg} / \mathrm{kg}$ & 8 & 8 & 22.2 & 23.6 \\
\hline
\end{tabular}

Values represent the average evolution of the number of mice and the average of weight. Number of animals used ( $\mathrm{n}=8$ ). ${ }^{*} \mathrm{p}<0.005$ compared to control by Friedman's test. * : P < 0.05: significantly different compared to control (CMC 2\%).

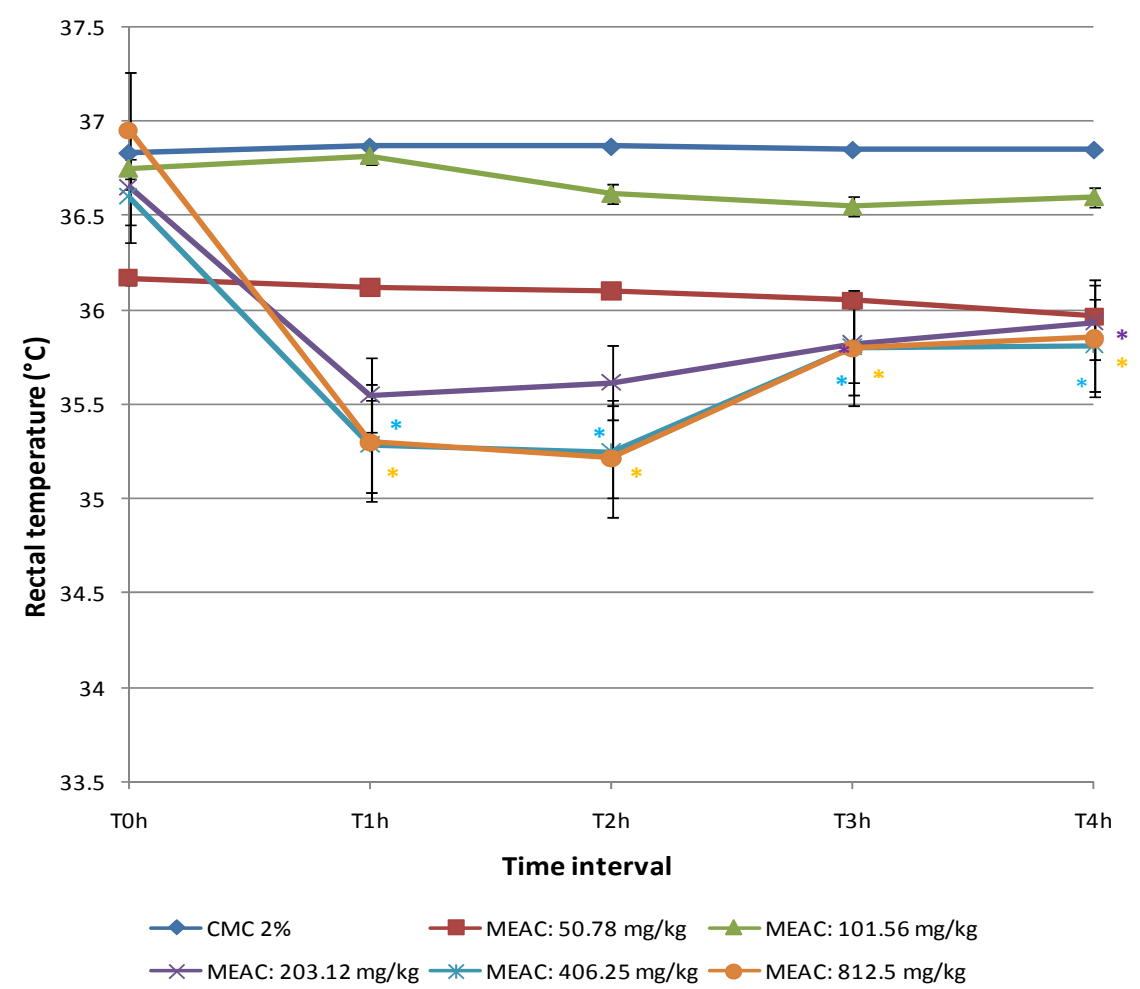

MEAC: Methanolic extract of Alchornea cordifolia; CMC: carboxyméthylcellulose Curves represent the average evolution of the rectal temperature in time. Number of animals used $(n=6) .{ }^{*} \mathrm{p}<0.005$ compared to control by Friedman's test. *: P < 0.05: significantly different compared to control (CMC 2\%).

Figure 1. Hypothermic activity of methanolicextract of Alchornea cordifolia. 


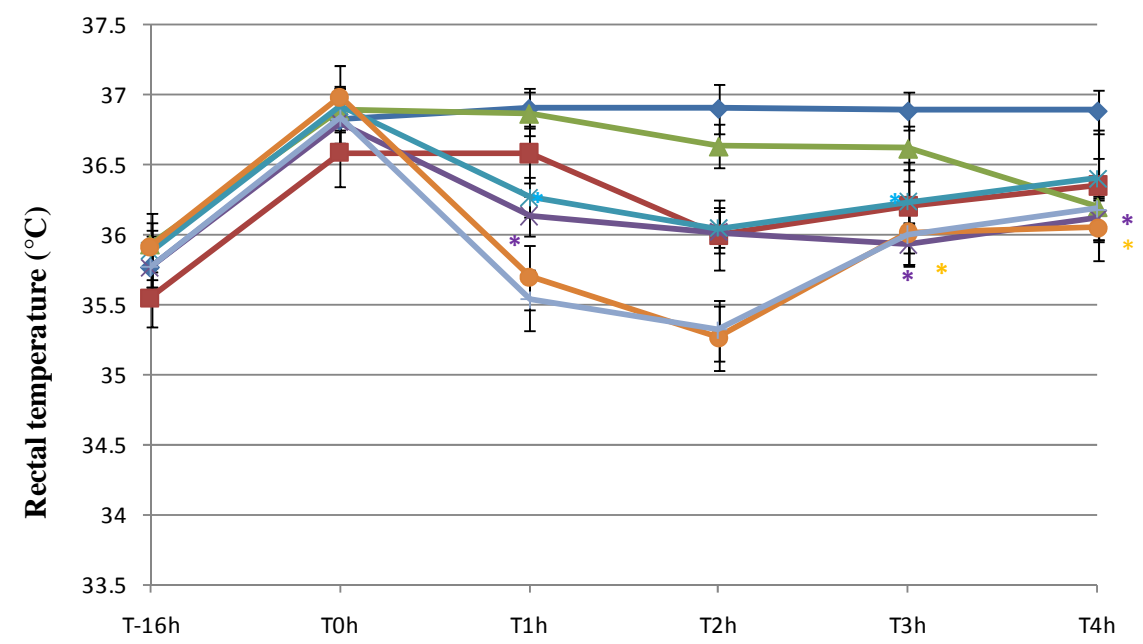

Time interval

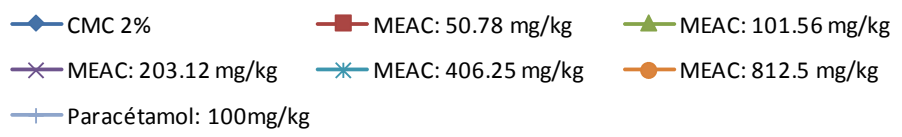

Curves represent the average evolution of the rectal temperature in time. Number of animals used $(n=6)$. ${ }^{*} \mathrm{p}<0.005$ compared to control by Friedman's test. ${ }^{*}$ : $\mathrm{P}<0.05$ : significantly different compared to control (CMC 2\%).

Figure 2. Antipyretic activity of methanolicextract of Alchornea cordifolia and paracetamol on brewer's yeast induced pyrexia in rats.

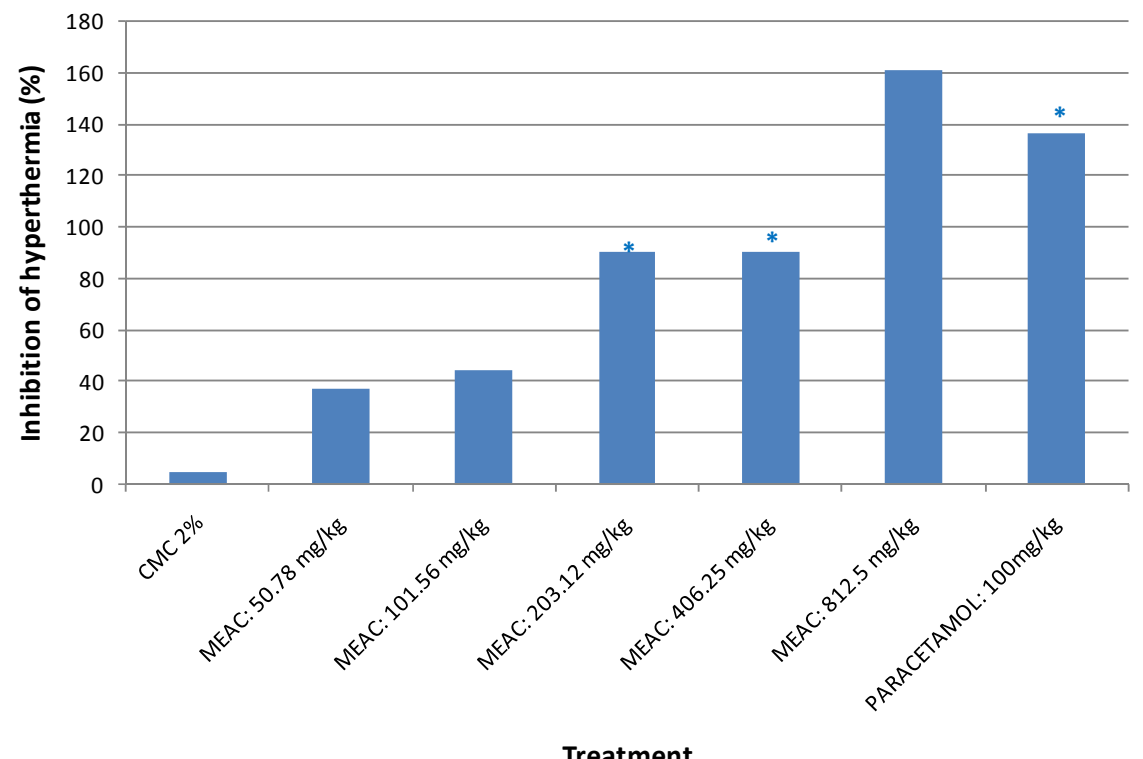

The results are given are mean \pm S.E.M. number of animals used $(n=6) .{ }^{*} \mathrm{p}<0.005$ compared to control by Friedman's test.

Figure 3. Inhibition of hyperthermia ofmethanolicextract of Alchornea cordifoliaand paracetamol (100 mg/kg) at two hours.

diseases associated with fever. Our works aimed to search out a possible toxicity and an antipyretic activity. About acute toxicity, absence of death in the present study was also observed by Traoré [15] using $5000 \mathrm{mg} / \mathrm{kg}$ p.o. of leaves orally and by Umukoro [12] using $4000 \mathrm{mg} / \mathrm{kg}$ orally. The absence of modification in the spontaneous movements shows that Alchornea cordifolia cannot modify the normal behavior in mice. However, the dose-dependent hypothermia observed in the present study after administration of Alchornea cordifolia extract showed acute toxicity of this plant. Hypothermia indicated alteration of preoptic anterior hypothalamus which is critical in 
the neuronal network of thermoregulation. The hypothalamus regulated the set point at which body temperature is maintained. Hyperthermia inhibition observed in the present work varies from $89 \%$ to $160 \%$. Evolution of hyperthermia inhibition due to Alchornea cordifolia at 812.5 $\mathrm{mg} / \mathrm{kg}$ during four hour was similar to paracetamol (100 $\mathrm{mg} / \mathrm{kg}$ p.o.) with a pick at two hours (Figure 2). The mechanism of the induced hyperthermia by brewer's yeast is mediated by prostaglandins biosynthesis $[16,17]$. Brewer's yeast administrated through subcutaneous route, behaves like an exogenous pyrogen. Thus, it produces an inflammatory process that according to Milton et al. [18] and Aronoff et al. [19], leads to the biosynthesis of chemical mediators as prostaglandins due to arachidonic acid. Among prostaglandins, PGE2 is strongly involved in the disturbance of the hypothalamic thermostat and so is responsable for fever $[18,19]$. Thus, the antipyretic activity of Alchornea cordifolia observed in this study would be related to the inhibition of the production of prostaglandins. Apart from their involvement in fever, prostaglandins are also known for their vasodilatation effect that generates red blotch and oedema as inflammation characteristics. Thus the hypothesis about the inhibition of the production of prostaglandins by Alchornea cordifolia could be uphold with the works by Osabede and Okoye [8] as well as those by Mavar-Manga et al. [7] highlighting the protecting effect of Alchornea cordifolia against oedema, the inflamemation model induced in rodent.

These antipyretic property lay in the saponins contain in Alchornea cordifolia leaves [5,9] that, according to Gepdiremen et al. [20] are strong prostaglandin inhibitors.

\section{Conclusion}

This antipyretic activity that is similar to paracetamol one could partly justify the traditional use of Alchornea cordifolia leaves against fever in the African societies. Considering the partially reversible hypothermic effect in a 4-hour observation time, we plan a more elaborate study on the neurotoxicity of that plant.

\section{Acknowledgments}

The authors are grateful to Pr. L. Aké-Assi (Centre National de Floristique d'Abidjan) for botanical identification.

\section{REFERENCES}

[1] E. J. Adjanohoun, "Fiche Espèce: Alchornea cordifolia," Bull Med Trad Pharm, Vol. 8, No. 2, 1994, pp. 203-213.

[2] A. O. Ajao, N.-O. Shonukan, B. FemiI-Onadeko, “Antibacterial Effect of Aqueous and Alcohol Extracts of
Spondias mombin and Alchornea cordifolia, Two Local Antimicrobial Remedies," International Journal of Crude Drug Research, Vol. 23, No. 2, 1985, pp. 67-72.

[3] A. Lamikanra, "Antimicrobial Spectrum of Alchornea cordifolia Leaf Extract,” Phytotherapy Research, Vol. 13, No. 1, 1999, pp. 67-69.

http://dx.doi.org/10.1002/(SICI)1099-1573(199902)13:1< 67::AID-PTR366>3.0.CO;2-F

[4] A. Lamikanra, A. O. Ogundani and F. O. Ogungbamila, "Antibacterial Constituents of Alchornea cordifolia Leaves,” Phytotherapy Research, Vol. 4, No. 5, 1990, pp. 198-200. http://dx.doi.org/10.1002/ptr.2650040508

[5] L. Tona, K. Kambu, N. Ngimbi, N. Mesia, O. Penge, M. Lusakibanza, K. Cimanga, T. De Bruyne, S Apers, J Tooté, L. Pieters and A. J. Vlietinck, “Antiamoebic and Spasmolitic Activities of Extracts from Some Antidiarroeal Traditional Preparations Used in Kinshasa, Congo,” Phytomedicine, Vol. 4, No. 5, pp. 31-38. http://dx.doi.org/10.1016/S0944-7113(00)80019-7

[6] J. T. Banzouzi, R. Prado, H. Menan, A. Valentin, C. Roumestan, M. Mallie, Y. Pelissier and Y. Blache, "In Vitro Antiplasmodial Activity of Extracts of Alchornea cordifolia and Identification of an Active Constituent: Ellagic Acid,” Journal of Ethnopharmacology, Vol. 81, No. 3, 2002, pp. 399-401. http://dx.doi.org/10.1016/S0378-8741(02)00121-6

[7] M. H. Manga, D. Brkic, D. E. P. Marie and J. Quetin-Leclercq, "In Vivo Anti-Inflammatory Activity of Alchornea cordifolia (Schmach. \& Thonn) Müll. Arg. (Euphorbiaceae), " Journal of Ethnopharmacology, Vol. 92, No. 2-3, 2004, pp. 209-214.

http://dx.doi.org/10.1016/j.jep.2004.02.019

[8] U. M. Teotino, L. P. Friz, A. Gandini and D. D. Bella, "Thio Derivatives of 2,3-Dihydro-4H-1,3-Benzoazin-4one Synthesis and Pharmacological Properties,” Journal of Medicinal Chemistry, Vol. 6, No. 3, 1963, pp. 248-250. http://dx.doi.org/10.1021/jm00339a007

[9] F. O. Ogungbamila and G. Samuelsson, "Smooth muscle relaxing flavonoids from Alchornea cordifolia," Acta Pharmaceutica Nordica, Vol. 2, No. 6, 1990, pp. 421422.

[10] R. Nia, D. H. Paper, G. Franz and E. E. Essien, “AntiAngiogenic, Anti-Inflammatory and Anti-Oxidant Potential of an African Recipe: Alchornea cordifolia Seeds," Acta Horticulturae, Vol. 678, 2005, pp. 91-96.

[11] G. A. Agbor, T. Leopold and N. Y. Jeanne, "The Antidiarrhoeal Activity of Alchornea cordifolia Leaf Extract," Phytotherapy Research, Vol. 18, No. 11, 2004, pp. 873876. http://dx.doi.org/10.1002/ptr.1446

[12] S. Umukoro and A. C. Aladeokin, "Evaluation of the Anti-Stress and Anticonvulsant Activities of Leaf Extract of Alchornea cordifolia in Mice,” Journal of Ethnopharmacology, Vol. 127, No. 3, 2010, pp. 768-770. http://dx.doi.org/10.1016/j.jep.2009.11.023

[13] E. Makonnen, A. Debella, L. Zerihun, D. Abebe and F. Teka, “Antipyretic Properties of the Aqueous and Ethenol Extracts of the Leaves of Ocimum suave and Ocimum lamifolium in Mice," Journal of Ethnopharmacology, Vol. 88, No. 1, 2003, pp. 85-91. 
http://dx.doi.org/10.1016/S0378-8741(03)00175-2

[14] N. Mascolo, R. Sharma, S. C. Jain and F. Capasso, "Ethnopharmacology of Calotropis procera Flowers,” Journal of Ethnopharmacology, Vol. 22, No. 2, 1988, pp. 211-221. http://dx.doi.org/10.1016/0378-8741(88)90129-8

[15] M. Traoré, “Alchornea cordifolia. SCHMACH (Euphorbiaceae): Revue des activités Biologiques et L'etude de la Toxicité. Université de Bamako, Mali, 2004, 107 p.

[16] R. Howard, "Preoperative and Postoperative Pain Control," Archives of Disease in Childhood, Vol. 69, No. 6, 1993, pp. 699-703. http://dx.doi.org/10.1136/adc.69.6.699

[17] J. R. Vane, “The Evolution of Non-Steroidal Anti-Inflammatory Drugs and Their Mechanisms of Action,” Drugs, Vol. 33, Suppl. 1, 1987, pp. 18-27. http://dx.doi.org/10.2165/00003495-198700331-00005

[18] A. S. Milton, "Prostaglandins and Fever," Trends in Pharmacological Sciences, Vol. 3, 1982, pp. 490-492. http://dx.doi.org/10.1016/0165-6147(82)91250-0

[19] M. D. Aronoff and E. G. Neilson, “Antipyretics: Mechanisms of Action and Clinical Use in Fever Suppression," The American Journal of Medicine, Vol. 111, No. 4, 2001, pp. 304-315.

[20] A. Gepdiremen, V. Mshvildadze, H. Suleyman and R. Elias, "Acute and Chronic Anti-Inflammatory Effects of Hedera colchica in Rats," Journal of Ethnopharmacology, Vol. 94, No. 1, 2004, pp. 191-195. http://dx.doi.org/10.1016/j.jep.2004.06.001 